\title{
HAMBATAN SEMANTIK DAN BUDAYA DALAM PROSES TRANSFER IDE OLEH MAHASISWA JURUSAN NON BAHASA INGGRIS DALAM PENULISAN PARAGRAF
}

\author{
TRANSFER OF IDEAS WITH SEMANTIC AND CULTURAL BARRIERS BY \\ S.N.E.D. IN A PARAGRAPH WRITING
}

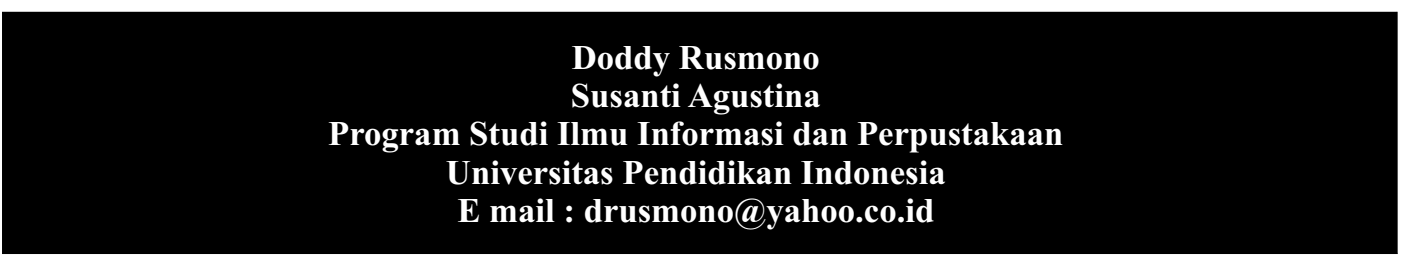

Abstrak. Proses transfer ide dalam bentuk tulisan yang dilakukan oleh mahasiswa jurusan ilmu perpustakaan dan informasi sebagai mahasiswa jurusan non Bahasa Inggris (SNED) yang mempelajari Bahasa Inggris sebagai bahasa asing (EFL) perlu diinvestigasi. Ketidakmampuan untuk menjembatani kesenjangan antara ide dalam bahasa ibu (Bahasa Inggris) dengan ide dalam bahasa pembaca (Bahasa Inggris) menghambat pemahaman pembaca, khususnya pembaca yang merupakan penutur asli Bahasa Inggris. Paragraf yang ditulis oleh mahasiswa SNED sebagai pembelajar Bahasa Inggris tidak dapat dipahami karena hambatan linguistik dan budaya. Sejumlah kecil mahasiswa yang membuat tulisan Bahasa Inggris dalam ujian tengah semester memperlihatkan gambaran ketidaktepatan dalam hal menyusun kalimat sehingga Bahasa Inggris mereka pada tingkatan tertentu terdengar seperti Bahasa Indonesia. Dalam hal ini kemampuan mereka untuk menggunakan Bahasa Inggris seperti layaknya bahasa Indonesia terbukti sangat rendah sehingga seorang penutur asli Bahasa Inggris yang mencoba untuk memahami ide mereka bisa salah memahaminya. Seorang pembelajar Bahasa Inggris harus memiliki kosakata yang cukup banyak dan setidaknya mengetahui aturan gramatikal seperti formulasi $9 B P+3 C C(C d, C x, C d x)$ dan PoS misalnya, untuk melengkapi pemahaman sebelum benar-benar dapat mengekspresikan ide dalam tulisan Bahasa Inggris yang dapat dipahami. Selain itu, pengetahuan mahasiswa tentang budaya penutur Bahasa Inggris memainkan peranan yang sangat penting untuk menghasilkan tulisan yang bagus, sebagaimana yang diungkapkan oleh seorang ahli bahasa bahwa seringkali seorang pembelajar bahasa mengetahui aturan tata bahasa tetapi tidak memiliki pengetahuan yang cukup tentang budaya penutur asli. Mahasiswa mengalami kesulitan dalam mengkomunikasikan idenya dikarenakan ekspresi suatu ide terikat oleh budaya yang merupakan entitas independen. Budaya penutur asli mempengaruhi dan membentuk perasaan, sikap, dan respons terhadap pengalaman dan interaksi seorang pembelajar bahasa dengan yang lain. Oleh karena itu, upaya fasilitator untuk memperbaiki kemampuan menulis mahasiswa mungkin untuk dilakukan.

Kata kunci: Penulisan paragraf, Bahasa, Kultur, Constraint, Betterment, SNED. 
Abstract. Ideas transferred in the written form by Library and Information Science students as SNED (Students of Non-English Department)learning English in the environments of EFL (English as a Foreign Language) need investigating. Inability of bridging the gap between the ideas in their native language (Indonesian language) and the audience language (English language)hampers understanding on the readers' part, as especially a native speaker of English language.

Paragraphs written by the SNED as English Language Learners (ELLs) are incomprehensible due to linguistic and cultural constraints. Quite a small number of students willing to write in English in their Mid-term Examination give some picture of inappropriateness in terms of sentence structuring resulting in their English being "Indonesian" to some extent. Their "at-homeness", in this case, proves to be so low that a native speaker of English trying to understand their ideas put into a paragraph will be more than likely misled. ELLs should have vocabularies in a sufficient number and know grammatical rules such as the one formulated as $9 B P+3 C C(C d, C x, C d x)$ and the PoS at least, for instance, to equip themselves with before actually expressing their ideas in comprehensible English writing mode. Other than that, ELLs' knowledge of target culture (English, that is) plays a great role in producing a good writing as coined by a linguist: Most frequently confronted that students to a great extent know the rules of language, but are not knowledgeable enough about the target culture. In communicating their ideas, students found it difficult to do due to a culture-bound independent entity of idea expressions. The target culture influences and shape the ELLs'feelings, attitudes, and responses to the ELLs' experiences and interactions with others. It is indicated that any facilitator's efforts towards betterments in terms of writing better paragraphs by the ELLs should be a possibility.

Key words: paragraph writing, linguistic, cultural, constraint, betterment, SNED. 


\section{A. Introduction}

The teaching of English as a
Foreign Language (EFL) to
SNED (Students of NonEnglish Departments) as ELLs (English language Learners) needs certain approach in encouraging them to write paragraphs in English in a more appropriate way. One of the SNED groups at FIP-Fakultas Ilmu Pendidikan (Faculty of Education) of UPI-Universitas Pendidikan Indonesia (Indonesia University of Education) is Prodi PerpusSainsInfo-Program Studi Perpustakaan dan Sains Informasi (Library and Information Science) group of students. To obtain a positive impact from the learning process through English I and English II lectures to the students of this category, for instance, a developed learning method through an appropriate approach is imperative. Not being "at home" in both cultures, this category of students write a bit less comprehensible paragraphs.

They are beyond awareness of the target language as a living phenomenon when transferring their ideas expressed in a written form. Thus, being familiarized with the target readers exists very little in terms of meanings: it communicates only the names of objects and different kinds of action but lacks in feelings, attitudes and beliefs. The culture of the foreign language does not really exist with adequacy in their written work.
One student, for example, wrote "The circle way is Difficult for explain, but in a side of picture, This way used for take the key words or conclusing this paragraph" brings no meaningful message to especially a native speaker of English, both in terms of syntax and semantics. The student writing the sentence was probably trying to write something like "It is difficult to explain how the circle way works when reading. The illustration below shows the use of key words to make a conclusion of the paragraph". The student does not seem to be familiar with the culture in which the language is used with the people who use it, their ways, manners, beliefs and all that goes into making a culture (Sofer, 1996:24).

ELLs should learn how to express their ideas when writing by involving themselves thoroughly. Hill and Flynn (2006:2) was cited when saying Language is the air we breathe and the water in which we swim. It comes as naturally to us as seeing the sky or digesting our food. It is as vital a part of our name and personality. But what if we suddenly had to breathe different air or swim in different water?

The culture in which the ELLs live influences and shapes their feelings, attitudes, and responses to their experiences and interactions with the target readers. Experts echoe this notion by saying that language represents the culture since the words refer to the culture, as belief and practices of a society, but the 
representation is never complete or perfect. The ELLs need to understand that what works in their first language (Indonesian language) may not work in English. They are impeded by this cultural relativity in that their attempts to achieve reader's comprehension have proven to result in communicating their ideas being less transferable: communication breakdowns being unavoidable. SNED as ELLs should be proficient in both their ideas and their audience so that the message they send to their readers is communicated accurately, clearly and naturally. Kaur (2006:77) says that ELLs should be able to deliver their ideas expressed in writing according to the rules, style, and grammatical points of the target language (English language) so that their message is avoided from being awkward and unnatural.

How challenging using English when expressing ideas come into action in writing is reflected by the above citation. ELLs should indeed have vocabularies in a sufficient number and know something about grammatical rules such as the 9BP+3C (Cd., Cx., Cdx.) and the PoS (Nine Basic Patterns of Sentence plus Compound, Complex, compound Complex sentences) and the Part of Speech, for instance, to equip themselves with before actually expressing their ideas in English in writing. One word, friend, as a key word, for instance, has five related words of companion, ally, closeacqu- aintance, crony, and confidant. To the ELLs, the five related words are "new" in that when they find them in a text, they would probably never know that the "new" vocabularies have the same meaning as friend. Actually, the Rapid Passive Vocabulary Acquisition technique may help them to enrich their vocabulary in a relatively short time. Say, for example, the technique could challenge the ELLs to memorize as many as 180 words in a convenient way and to their pace through 3 lists of key words consisiting of 12 each to gain 5 related words. Another technique the ELLs would find it challenging could be paraphrasing. The technique of paraphrasing a piece of writing means writing a passage that has exactly the same meaning as the original piece of writing but is different enough in both the choice of words and the arrangements of ideas. If, for one way or another, the ELLs' ideas put into a writing form have to be made "different" in a way, the technique may well facilitate to reach the "difference". This technique offers them five tips namely: 1) use synonyms; (2) use varied sentence patterns; (3) change the order of ideas; (4) break long sentences into shorter ones; and (5) make abstract ideas more concrete. They may use the word beautiful which has synonyms such as lovely, gorgeous, pretty, and smashing. To write a sentence Dwi Retno is the most beautiful student in this class, for example, ELLs might want 
to use the technique by writing the sentence like Dwi Retno is the loveliest student in this class, or, Dwi Retno's beauty is incomparable in this class, or, Nobody in this class is as smashing as Dwi Retno, or, Nobody is pretty in this class but Dwi Retno. Depending on how meticulous the ELLs are, the ideas they express in writing could be varied the accepted way in English.

Other than that, ELLs' knowledge of target culture of the language (English, that is) plays a greater role as coined by Cakir (2006:77) “Most frequently confronted that students to a great extent know the rules of language, but are not knowledgeable enough about the target culture." As a communication tool with two parallel streams which prompt to an awareness of a difference between the languages, it makes it possible for any sociocultural and sociolinguistic constraints to hamper the communication.

In the English learning as a second language (ESL) as in Singapore, for instance, ELLs are involved in English language in their daily life while in the case of English learning as a foreign language (EFL) in Indonesian ELLs, acquisition and the use of the English language depends and is limited to the learning structure in the classroom with all of its impacts (Macau, 2003:149). It is true that one of the eight weaknesses in using a language is when an idea is expressed, emotional tendency and being swerved in nature often happens. An instructor with the capacity of facilitator needs to always make an effort to ameliorate the natural inapropriatenesses in the light of teacher demeanor the unforced mistakes done unintentionally in writing a paragraph. For the ELLs as in the case of Indonesia to have an atmosphere of English environments, big endeavour must be undergone. This happens most frequently in the efforts of using English when speaking in a public environments. Students whose local language is Sundanese, for example, will take a big risk when using English to communicate with other friends of the same level of "mastery" in front of people who know English. These heavily influenced local speakers of Sundanese language want to speak the normal accepted English. However, acceptance in the "right" way in the target receiver is unavoidably colored by an element of locality such as mispronouncing words although an expert of English pronunciation says that No two people pronounce exactly alike. Differences among individuals exist from various causes such as locality, early influences, and social life of people living around a place forming certain environments. Not to mention individual peculiarities difficult or almost impossible to be discussed.

The present study using a qualitative approach sought to identify and describe a phenomenon prior to 
analysis. Stark and Torrance (2006:27) insist that case study assumes that social activity is created through social interaction, albeit situated in particular contexts and histories, and seeks to identify and describe before trying to analyse and theorize. Analised types of paragraph writing in English include measurements of different phenomenon of source culture and target culture. Acquisition of English words as a foreign language by the ELLs is also worth investigating through the use of multiple sources of evidence (Yin, 1981:91). Reasons and the way chosen in terms of writing with quality are discussed in an inductive mode of explanation to generate understanding.

\section{B. Discussion}

\section{Potentials of Producing Inappropriatenesses}

The less comprehensible part of the student's ideas expressed in writing might happen without their being aware. Efforts of generating betterments by the facilitators should always prevent the students from being exposed to an atmosphere that possibly reveals some embarassement especially a very personal one as discouragement could emerge. The ELLs would feel secure and, as a result they are sure that they are freed from any kinds of intimidation. They will therefore see a big chance to have an access to an enlightenment pleasing theirhearts lead- ing them to getting rid of hestitation in expressing their ideas in a written form. That way, confidence goes hand in hand with every single sentence they write in a paragraph.

Sources of inappropriatenesses referring to the absence of linguistic and cultural aspects in the writing contributes to the message not delivered to its target readers. To reach their readers affectively, a piece of writing must not only be complete and accurate, but also grammatically correct, stylistically appropriate and terminologically consistent. Since expressing ideas in English is the accurate rendering of an idea into another language, it has to be suitable for its intended purpose. English has collocations, and it is the writer's task to transfer the meanings of the collocations into the target audience in order to be understood. In the present study, they are readers from all walks of life. Combinations of words will differ from language to language. For example, in English, an expression running like $\mathrm{He}$ suffers trouble might be expressed He sees trouble or He drinks trouble in Indonesian or other languages. Different words are combined to indicate meaning but they are likely to risk some loss of meaning. In collocations, the meaning cannot be worked out from the meanings of the individual words. All in all, collocation is an expression consisting of two or more words that correspond to some conven- 
tional way of saying things or, collocations of a given word are statements of the habitual or customary places of that word.

Cultural environments contribute to the creation of English atmosphere. This time, for the sake of comparison, not communicating using the media of writing but the media of individual oral skill. Differences among individuals exist from various causes like, for example, locality. This would lead to a social life of people living around a place forming certain environments. Not to mention individual peculiarities difficult or almost impossible to be discussed. A good example would be the locality as happened in, say, Bandung city of the Province of West Java, Indonesia. People, to be more specific, students whose Sundanese (a local language of people living in West Java Province of Indonesia) accent is so strong pronuncing " $\mathrm{f}$ " isntead of " $p$ " and vise versa. When a word which has a " $p$ " in it is to be pronunced, an " $\mathrm{f}$ " is heard such as in a word "people" which is pronunced "fifel". Students having an English session in a classroom often burst into laughter when one student whose locality is so strong has to pronunce the sentence running like "It's very difficult to park my car in this parking lot" where the "p" is pronunced "f" and the "f" is pronunced " $p$ ". It is exactly what other students with the same locality would pronunce every time the consonants of "f" and "p" are parts of a word. Thus, a student might trigger some laughter when a pharse of Novia Kolopaking, a name of famous Indonesian artist, is pronunced Nopia Kolofaking.

Students do not seem to care with considerable degree the theories and rules in writing a paragraph. Other than being not precise in terms of the modes of writing in that almost none of the four modes of writing (argumentative, descriptive, expository, narratative) is referred, topic sentence in the paragraph is not followed by supporting sentences sticking together to one another to form a coherence. To make things worse, the idea expressed to communicate the message is a bit far from being informative. This informative idea should actually operate in a type of configuration reflecting a certain emphasis in that the focus is primarily on the message which must be described in terms of the message (Baker, 1992: 47-62). It is evident that the students playing the role as beginners in writing in this study face difficulties as they have to provide meaningful equivalent message items: providing identifiable equivalences in the culture of the target language (English language). The ELLs are supposed to analyze and describe the cognitive equivalences of the message. As a secondary source, the ELLs must attempt to view their readers from the perspective of their monolingual comprehension of the message written so 
as to make it attractive and elegant: the ideas expressed should necessarily be a pleasure to read.

Student's writing violates, to some extent, the theories of academic writing in that they transfer their ideas in their original language their own way and, to a certain degree, they are sure that theories are far more implicit than explicit. Most students in this case study indicate that for the most part they have little or no use for the various theories of writing: the theories being regarded as not worth learning. What can be drawn from this phenomenon is that students regularly and consistently violate so many rules laid down by theorists. In regard to the difficulty of relying heavily on the principles and rules of writing, it is also evident that the informants find their ideas constructed in their first language so heavy in theme-related technical terminology that they sometimes need to give illustrative examples.

One difficulty of achieving accepted ideas expressed in writing is to provide a meaningful equivalence in the form of written expressions. Content of the expressions should be treated in such a way that a discourse is clearly distinguished from its setting, especially when the setting of ideas in the source language (Indonesian language) is widely divergent from any corresponding setting of ideas in the receptor language (English language). It proves to be difficult to trans- port the reader to the setting of the source language and thus providing a cultural setting of the student's creativity for the corresponding cognitive messages is quite a possibility. Nord in Dollerup.ed. (1994:51) and Nababan (2003:94) contend that purely linguistic equivalence between elements of language system has proven inadequate as a criterion for the transfer of complex expressions. It explains, therefore, that doing away with making efforts to meet equivalence would seem appropriate to some extent. Accordingly, with the analogy type of identification, as found in the Witte's scopos theory (Dollerup.ed.,1994: 69-71), emphasizing the importance of intercultural communication skill: a writer should be biculturally competent. Providing illustrative examples and attempting an explanation of the significance of the source language in appended expressions to achieve an equivalence digestible to the intended readers involve a problem in that simply a transfer of ideas would not be sufficient. Consequently, most writers in the present study seem to feel free to alter the cultural features of the source language in the message transferred while taking the risk of generating some loss of meaning.

\section{Efforts towards Possible Betterments}

Making efforts to make sentences in a paragrpaph sound as digestible as possible will always bring with it some positive 
impacts. As a facilitator, giving unvafourable remarks on the ELLs's writing performance should be avoided. Experts in linguistics insist that it is a must to give remarks on student's work that will have a positive impact meaning that students as ELLs should be freed from double burdens: linguistic and cultural shortcomings. Even more crucial is that students should be avoided from building a less promising mental achievement. It is suggested therefore that if uselessness is what follows after the remarks, even worse painfulness deep in the student's heart, giving remarks should be halted. As experts say, preventing ELLs from comments unlikely bringing positive effects is a brilliant idea. Every student has his own secret in his journey to writing a good paragpraph, but no one should reveal the secret for whatever reason. In their first year of learning, having difficulties in syntax and semantics proves to be common. Let alone a cultural sense of a foreign language. To SNED, empowering themselves through various opportunities of learning is a certainty. The SNED need to be encouraged to adapt what they are really interested in with the aims their instructors are attempting to achieve. Through a collaborative writing technique, for instance, SNED are offered to interact with each other in group activities to arrive at their learning intensity. Allen (1974:91) mentions some fundamentals as follows These two gene- ral principles are self evident: 1) All students want to speak, write, and read the normal accepted English today; 2) This commonly be achieved by constant practice of existing forms, with some rational explanation of grammatical devices employed, whenever this $s$ possible. It is true that basically students as ELLs want to have their ideas especially those put in a written form comprehensible in the target language when trying to communicate with their readers.

A script as written by ELLs falling into the category of SNED was found. The script runs like

Okey guys, this is Multimedia Room. There is place for browsing, searching, downloading, and typing. All facilities this room free for user. And this is postgraduate room. We can access in repository upi for see this collection. Now, we will wend second floor. This library have relict deposits. Okay, this is magazine and France Corner. This room will be relaxing for user. And than user can copy essay, thesis, disertasi and other collection in foto copy room. Free from copy can using preservation of collection

All parts of the script above are performed exactly as it is written the way they look. The purpose is to give a good example of how incomprehensible an idea expressed is in a wrtten form. The word wend, for instance, is written as it is in the original script. The word "went" is probably meant in the first place although it should actually be "go". 
To foreign students coming from English speaking countries like The USA and Canada, for instance, technical explanation on how to use electronic searching tools to access library resources could be unclear because of the explanation being not equipped with sufficiently appropriate diction.

Other Indonesian-culture-loaded expression in an oral form was found. This time cultural restraints are exposed in an examination session. At a formal examination of Ujian Sidang Sarjana to promote undergraduate students of the level of educational program in the department eligible to graduate, a simple question like "Are you sure, your offer of applying such technique is promising enough knowing that instructors are usually find it a bit difficult to change their own ways of giving lectures? could turn out to be hard for the examinandus (the SNED student, that is) to grasp its meaning. The examiner was trying to test the examinandus' knowledge of using English to see whether the student can make his qualification meet the actual competency in the Era of Free Trade (and the university's motto of Leading and Outstanding University) he is going to face once he has to involve himself in the era of challenge. Answer to the question was In my experience, teachers want to apply it sound a bit Indonesian being mistakenly expressed in English. Not only the pronoun it which does not represent the word techniques but also the phrase In my experience which is not in parallel with the words teachers want. The student would probably wants to say something like As far as I am concerned, the informants of my research are willing to apply them (the techniques). Or, Yes, I am quite sure. To the best of my knowledge, the respondents show some willingness to apply the techniques. There's no doubt about it, Sir. The degree of cultural distance between the SNED and say, a Canadian native speaker, for instance, remains high.

At another chance in a Q\&A (Question and Answer) session, a keynote speaker (an American native speaker) of an international seminar finds it rather hard to get the meaning of a question running like "What could you relate between title from outside, grades, and behavior for students?" Even though it is hard to draw the common thread from the question, the keynote speaker manages to entertain what is asked by the questioner (an ELL of SNED reading his note when asking the question, that is). At least, the keynote speaker would interpret "How would you see any relationships between academic degrees earned from abroad and the behavior of grading students' work among lecturers?" before actually answering the question. The following question is short but sounds less accurate "Can the best teaching method guarantee the best alumni?" 
The gap of diction between a sense of process and a sense of product seems to be too big for the native speaker to handle. Part of the reason as for the Indonesian ELLs finding it hard to adopt the culture of foreign language is that unchangeability. Trifonas (2005:197) makes it clear that any given culture is essentially a peculiar narrative, a mythos, that unites individuals by adopted assumptions and practices, and that is generally resistant to change. Forcing themselves to be "at home" with the linguistic culture of the foreign language results in somewhat awkward expressions: message not undesrstood. Palfreyman (2003:20) insists that "self" refers to private, subjective aspects of the individual. Self is the essence of the individual, reporting as "I" - what makes me me, different from everybody else. Then, it explains that expressing ideas involving one's own culture ends up with a sense of "nothing should be a problem" on the individual's part.

Reaching to be "at home" with almost impossibility in terms of culture of other language, possible causes of transferring ELLs's ideas expressed in a written form incorrectly prove to be, as Sofer (1996:129) says. First, inability of applying syntax in identifying words, phrases or subordinate clauses which function as core elements of especially complex sentences not common in the source language (Indonesian language).
Second, when transferring their ideas, ELLs are being more semantic rather than being both semantic and cultural in expressing their ideas. Third, which is emphasized in the present study, their being unable to bring the gap between their ideas in their first language and their message to be sent to the target language: transferring. Two paragraphs developed by one of the ELLs run like the following transfer of ideas.

\section{Hiking in Kramat Mountain}

Last week, I and my group gone to Kramat Mountain in West Java. Me and six of my friend have prepared everything that we need and can we bought to Kramat Mountain. In Friday, we started our vacation from Indonesia Education University with a vehicle called ELF. We arrived in Circle Village at 05.00 P.M. So, we chosed to maked a tent for sleep. In the night, we cooked some food for diner. And then we sleep to keep our stamina.

In the morning, we prepared to hike Kramat Mountain. We started oour journaey in 08.00 A.M. At 11.30 A.M. we arrived the top of Kramat Mountain. We ate some snack and take photos in the top of Kramat Mountain. At 1.30 P.M. we chose to down the mountain. At 5.30 P.M. we arrived in Jaya Giri, Lembang. And we search a vehicle to brought we to campuss.

The above paragraphs are loaded with a number of mistakes made unintentionally. Upon an interview with the ELL as an informant of the study, it was found that he intended to write the normal accepted English. Any native speaker of English would probably find it hard to understand what the ELL was 
trying to tell because of the vacabularies chosen and of the structures used. Transitional markers are not really used to describe chronological order of time making it potentially strong to swerve the intended meaning of the writer on the reader's part. All the sentences are not sticked together to facilitate the coherence and thus preventing the flow of a story from taking place. This instance of improper transfer of ideas shows an elementary errors and is evidently rampant. The whole story which is actually interesting fails to reach its reader in a meaningful sense. Bridging the gap between the ELL's ideas and the target reader does not work in that the hinge between the ELL's ideas put into deep structured sentences and the appropriate restructuring of meaning within the target reader's language is not built.

Another typical mistakes of the ELL's productive skill is shown below.

\section{Begal is Crime}

Crime is a big problem in some coountry, especially in Indonesia. For example in Bandung city there was looting motorcycle on the street. Crime is an act that breaks a law that relates to how behave society Begal is one of crime activity who was popullar right now. The Begal is exist because economic factor and low education in some area. The solution is rider must be carefully if riding in the night. The police must secure the roadintensive.

The ELL writing a very simple paragraph achieves some equivalence with flaws. To reach some understanding on the reader's part, he should use primarily semantic and secondarily cultural methods. This way, he could be freed from making mistakes and risky senses of meanings. He actually wrote the paragraph at his original linguistic level. As a consequence, the paragraph results in his emphasizing on his ideas more than he did at the readership's. It is possible that the ELL used the semantic method of transferring his ides because it is compromising, more fexible and it gives him a room to create with his intuitive empathy with his original message. His attempts to communicate his ideas expressed in a written form is meant ot emphasize on his message being accepted by his target reader. The whole paragraph indicated that he encountered difficulties in constructing a new reader with different textual expectations and culltural knowledge from his. It can be identified that his bias in considering the essence of the message ends up with insufficiency of reader's understanding.

The following very short two-parapgraph essay represents a bit less pleasant to read.

Bright Future of Librarians Librarian is a professional man who can manage a library. Not only a shelving, but they are do another li rary's activities such as: selecting books, classifying books, distributinng books and also do some library's services (circulation, references, reserved, journal, and others). Every librarian ough to be a professional workers. Someone who want to be a libra- 
an should get a training or formal educating like school. The first librarian school is in US and UK, and then librarian school starts developing to another countries, included Indonesia. (even I can say it's still minority). So, to be a librarian is need some years to studying and of course so much money to school.

But people's perception is still negative to an image of librarian. So many people said that librarian's job is only keeping a book and librarian's office is in a dark, dusty and uninteresting places. In fact, some Indonesian libraries is not good enough. The places is bad and they don't have a librarian. In this case, this is a new-born librarian tasks to create a good and proper libraries for Indonesian peoples. It's actually hard to get that goals, but that's the real librarian job. And I think this is new-born librarian's big opportunities to get such a good and many jobs. Then, the conclusion is actually Indonesian librarian have a bright future.

Every single word written in the above paragraph is rewritten exactly as it appears in the ELL's writing. It is worth noting that difficulties in transferring his ideas in his own language (Indonesian) to other's language (English) deal with linguistic and cultural aspects. To facilitate their target reader, the ELL takes into account the fact that what he transfers is a linguistic and cultural interaction. The ELL keeps giving rooms for risking some loss in transferring his ideas to his reader by making his Indonesian ideas put into Indonesian way of using English without adopting such things as the culture in which the language is used with the people who use it, their ways, manners, beliefs and all that goes into making a culture. As a second semester student, the ELL is still in the middle of getting familiar with those things concerning a target culture and the linguistic aspects of a language. In the ELL's mind, transfering ideas to facilitate his target reader could mean the same as translating his ideas into the target language using a word-for-word method, purely what he wants to express. To the reader, there is a need to know what the writer means with his ideas and not just what he writes.

Outside the classroom, at an activity of Student English Forum chaired by students falling into the category of SNED of Library and Information Science, various kinds of introducing oneself is heard. One note written by one of the students read to the audience is interesting to be discussed "Hi! I am Vinny. I live here in Bandung. Although my English is not very good, but Ijoin this club to have fun". There is a possibility that the introduction is translating an Indonesian idea into English without carefully integrating grammatical elements to the expression. It seems like it is meant to minimally fulfill the need for information just to let people know something little about somebody. No signs of interests are offered in terms of newnesses. No indication is found that the introduction would be continued in a more attractive and interesting way. It is therefore interpreted that no intention of giving signals that the first dialog could 
bring with it an impression of warmth and invitation to an even pleasing friendship. Vinny would need time and patience to reach a certain level of proficiency so as to have an expression more or less "right" like Hi, there! My name is Vinny Christy Budiono but you can call me Vivin. I am interested in joining with this club of conversation just because it looks good the way it is. It also sounds like fun when I see you all together in a harmonious atmosphere - chatting, laughing, and having all possible good times. In my spare time, I go swimming. Sometimes I swim alone, all by myself. The last statement has every reason to attract interests and thus serves as a good start to build a relationship in a convenient atmosphere. Seeking for harmony (Garcia et.al., 2014:127) is what Vinny is not well equipped in terms of, for example, certain Western culture. At a glance, the case of mistake as shown above looks trivial, but a closer examination suggests that it inspires one to make some betterments. An alumnus' opening remark in his capacity as a moderator in an international conference needs to be polished because the remark runs like "Welcome for Mr. X". The preposition used in the remark should not actually be there and other, to, should be a substitute. A candidate for The Best Educator award at a faculty level who speaks in English with difficulty when answering a juror's question is a good example of less - than - communicative
English used due to both linguistic and cultural constraints. The candidate's competency of English should actually be in the category of "speaking effortlessly" already or, to make it comparable, in writing when it comes to trasferring ideas.

\section{Conlusion}

Making efforts to elevate any good intentions of the SNED as ELLs to write a paragraph in English may never be futile. The instructors playing the role as facilitators approaching the students with enthusiasm results in positive responses and would eventually end up with betterments in various forms. Rooms created for the ELLs to fill the gap between their own language cultures and foreign language cultures may still be far from being perfect. Nevertheless, at least an initiative has been launched and will hopefully lead to a much more promising future. Giving credits to the students for any drives of writing in English proves to be conducive. It leads to an emerging self confidence on the ELLs's part and, as they go along, will generate more comprehensible communication in written form. Varieties of cultural and linguistic backgrounds will not contribute that significant to hampering incomprehensibility and will therefore ameliorate constraints to effective learning. Students will benefit a great deal from their learning. 
Temporary "negligance" to linguistic and especially cultural standards has resulted in a conducive process of learning English as a foreign language. It may even enrich the existing "Englishes" in a way. Replacement of the negligance by the facilitator's artificial conduct of enlightenment drives ELLs to perform with confidence and with the feeling of being not intimidated by risks. Benefits are the ELLs to gain since continuous efforts of creating pleasing atmosphere by the facilitators are endlessly made. The aim is obvious: an initiative to write in English with confidence and risk-free attempt. The impact is potentially promising in terms of developing and implementing innovative instructional program for the SNED as ELLs.

\section{Bibliography}

Allen, WS. (1974). Living English Structures.5th ed. Aylesbury, Bucks: Hazel Watson \& Viney Ltd.

Baker, M. (1992). In Other Words: a course book on translation. London: Routledge.

Cakir, I. (2006). Developing Cultural Awareness in Foreign Language Teaching. Turkish Onlinejournal of Distance Education TOJDE.vol.7\#3.

Garcia, Fredi et.al. (2014). Cross Cultural, Values and Ethics Differernces and Similarities between the US and Asian Countries. Retrieved from www.emeraldinsight.com/17468779.htm.
Hill and Flynn. (2006). Classroom Instruction that Works with English Language Learners.

Alexandria: ASCD.

Kaur, K. (2006). A competent Translator and and Effective Knowledge Transfer. Kuala Lumpur: University of Malaya Press.

Macau, CM. (2003). Through Translation: considering multiple intellegencies.London: Oxford University Press.

Nababan, MR. (2007). Translation Process and Strategies: two case $s t u d i e s . \quad A v$ a i $1 \mathrm{a} \mathrm{ble}$ online:usd.ac.id/06/pub/_dosen/ph enomena/feb 07/nababan.pdf.

Nord, C. (1977). Translating as a Purposeful Activity: functional approaches explained. Manchester: St. Jerome.

Palfreyman, David and Richard C. Smith.eds. (2003). Learner Autonomy across Cultures. Language Education Perspectives. New York: Palgrave macmi ltd.

Sofer, M. (1996). The Translator's Handbook. Rockville: Schreiber Publishing.

Stark and Torrance. (2005). Research Methods in The Social Sciences. London: SAGE Publication.

Trifonas, Peter Pericles.ed. (2005). Communities of Difference: culture, language, technnology. New York: Palgrave macmi ltd.

Yin, R.K. (1981). Case Study Research: design and Methods. California: SAGE Publication. 